\title{
SOME INVESTIGATIONS ON THE METABOLISM OF PHENYLALANINE AND TYROSINE IN CHILDREN WITH VITAMIN C DEFICIENCY
}

\author{
BY \\ T. H. J. HUISMAN and J. H. P. JONXIS \\ From the Department of Paediatrics, University of Groningen, The Netherlands
}

(RECEIVED FOR PUBLICATION AUGUST 13, 1956)

Scorbutic children excrete some amino-acids in amounts higher than normal in their urine (Jonxis and Huisman, 1954). Serine, threonine, glycine, histidine, lysine, $\beta$-amino-isobutyric acid, glutamic acid in bound form and also tyrosine are excreted in increased amounts. It has been known for a number of years that vitamin $C$ is necessary for the normal metabolism of tyrosine. Levine, Gordon and Marples (1941) found that a number of intermediates in the metabolism of tyrosine appeared in the urine of premature infants when these infants received a diet high in protein and without vitamin $C$. The same was found when relatively large amounts of tyrosine or phenylalanine had been added to the food. When vitamin $\mathrm{C}$ was given the excretion of the tyrosyl substances decreased. Sealock and Silberstein (1940) found that giving high doses of tyrosine to scorbutic guinea-pigs increased the excretion of homogentisic acid, para-hydroxyphenylpyruvic acid and para-hydroxy-phenyl-lactic acid.

When L-tyrosine is given to scorbutic infants (Morris, Harpur and Goldbloom, 1950; Woodruff, 1950), to human adults (Rogers and Gardner, 1949) or to scorbutic monkeys (Salmon and May, 1950, 1953) the excretion of tyrosyl substances in the urine is increased. After administration of vitamin $\mathrm{C}$ the excretion of these tyrosyl substances diminishes. In order to learn more about the tyrosine metabolism in children with scurvy, we have studied the influence of oral doses of phenylalanine and tyrosine on the plasma levels and the excretion of these and other amino-acids in three scorbutic children and one normal child.

\section{Case Notes}

The first child, a boy of 17 months, with a body weight of $8.4 \mathrm{~kg}$., was admitted to hospital because he had painful legs. At home he had been mainly fed on pasteurized milk which was subsequently boiled. He had had some vegetables, but these were mostly cooked twice.
It is very doubtful whether he ever ate any fruit, but he had received vitamin D regularly. There were no signs of rickets; the serum calcium level was $10 \cdot 8 \mathrm{mg}$. per $100 \mathrm{ml}$., the inorganic phosphorus $5.4 \mathrm{mg}$. per $100 \mathrm{ml}$., alkaline phosphatase 14.4 King-Armstrong units per $100 \mathrm{ml}$. A radiograph of the knees and wrists showed fully developed scurvy. There were periosteal haemorrhages of the femora, but he had no haemorrhages in the skin or gums. The concentration of vitamin $\mathrm{C}$ in the blood was less than $0 \cdot 1 \mathrm{mg}$. per $100 \mathrm{ml}$.

In hospital the child was given a diet with $1.2 \mathrm{~g}$. of protein per $\mathrm{kg}$. body weight. A 24-hour specimen of urine was collected. The next day he received in addition to food $1 \mathrm{~g}$. of DL-phenylalanine each hour orally over a period of 10 hours (L-phenylalanine was not available to us). The urine was collected during this period and the next 10 hours. Some days later the same experiment was repeated, but instead of DL-phenylalanine, L-tyrosine in the same amount was given. Thereafter he was given $100 \mathrm{mg}$. vitamin $\mathrm{C}$ daily. With this treatment he soon recovered and the radiological signs of scurvy quickly disappeared. It was not possible to get enough blood from this child to determine the plasma amino-acid composition.

The second child was a boy of 7 months with a body weight of $7 \cdot 8 \mathrm{~kg}$. He was admitted to the hospital with the diagnosis of tetany. His only food had been boiled pasteurized cow's milk with sugar; neither vitamin $C$ nor vitamin $\mathrm{D}$ had been given. On admission the concentration of vitamin C in the blood was $0.3 \mathrm{mg}$. per $100 \mathrm{ml}$., serum calcium $7.5 \mathrm{mg}$. per $100 \mathrm{ml}$, inorganic phosphorus $4.4 \mathrm{mg}$. per $100 \mathrm{ml}$. and alkaline phosphatase $61 \mathrm{King}-$ Armstrong units per $100 \mathrm{ml}$. A radiograph showed signs of rickets and perhaps of scurvy. The child was given 300,000 i.u. vitamin $D_{2}$ and was fed with boiled pasteurized milk without the addition of vitamin $C$ for the next 14 days. At the end of this period the serum calcium level was $10.5 \mathrm{mg}$., inorganic phosphorus $7.6 \mathrm{mg}$. per $100 \mathrm{ml}$. and a radiograph showed that the rickets were healing. The vitamin $\mathrm{C}$ concentration in the blood was now 0.2 per $100 \mathrm{ml}$. In the next few days he was given $10 \mathrm{~g}$. of DL-phenylalanine as described above for the previous child. Five hours after the first dose of phenylalanine a blood specimen was taken to determine 
the plasma levels of the various amino-acids. In this case we were not able to collect the 20-hour urine specimen during the phenylalanine administration.

The third child, an 8-month-old girl with a body weight of $7.4 \mathrm{~kg}$., had been sent to the hospital with a diagnosis of tetany. She also had been fed on pasteurized milk with sugar, and had received no greens or fruit. A radiograph showed moderate rickets and scurvy. The vitamin $\mathrm{C}$ concentration in the blood was less than $0.2 \mathrm{mg}$. per $100 \mathrm{ml}$., serum calcium 5.9, inorganic phosphorus $6 \mathrm{mg}$. per $100 \mathrm{ml}$., alkaline phosphatase 61 King-Armstrong units per $100 \mathrm{ml}$. The child was given 300,000 i.u. vitamin $\mathrm{D}_{2}$ orally and calcium gluconate intravenously, but no vitamin $\mathrm{C}$ was added to the food. After a fortnight a radiograph showed healing of the rickets. The blood levels for phosphate and calcium were about normal at that time: serum calcium $9.8 \mathrm{mg}$. per $100 \mathrm{ml}$., phosphate $5.5 \mathrm{mg}$. per $100 \mathrm{ml}$.; alkaline phosphatase was still high, $66 \cdot 6 \mathrm{King}$-Armstrong units. The vitamin $\mathrm{C}$ concentration in the blood remained low during this period and 14 days after admission was $0.2 \mathrm{mg}$. per $100 \mathrm{ml}$. Then $10 \mathrm{~g}$. L-tyrosine were given in oral doses of $1 \mathrm{~g}$. each hour; five hours after the first dose blood was withdrawn for the determination of the different amino-acids.

A normal boy, 14 months old, body weight $8.4 \mathrm{~kg}$., who received a diet with $1.4 \mathrm{~g}$. protein per $\mathrm{kg}$. body weight, served as a control. This child had been given 800 i.u. of vitamin $D_{2}$ and $50 \mathrm{mg}$. vitamin $C$ daily for the previous weeks. He was given $10 \mathrm{~g}$. of DL-phenylalanine and $10 \mathrm{~g}$. of L-tyrosine with an interval of about one week. Both times blood was withdrawn five hours after the first doses, and a 20-hour specimen was collected.

\section{Methods}

The total amino-acid concentrations in blood and urine were determined using the Van Slyke ninhydrin method (Van Slyke, Dillon, MacFadyen and Hamilton, 1941). The separate amino-acids were estimated with ion-exchange chromatography. A slightly modified gradient elution technique of Stein and Moore was used (Stein, Bearn and Moore, 1954; Moore and Stein, 1954). The concentration of the different amino-acids in the plasma was determined by the same method. In this case a protein-free ultrafiltrate of the plasma was used as has been described previously (Huisman, 1954). For the determination of the tyrosyl substances the method of Medes (1932) was used. The total concentration of keto-acids was measured by the technique described by Felix and his co-workers (Felix, Leonhardi and Glasenapp, 1951; Felix and Schaefer, 1950). For the determination of the homogentisic acid the iodometric titration method of Neuberger (1947) was used.

\section{Results}

Table 1 gives the values for the excretion of alphaamino nitrogen before and after hydrolysis in the urine of the first patient and of the control before and after the phenylalanine and tyrosine loads. As has been described previously (Jonxis and Huisman, 1954), the alpha-amino excretion of the scorbutic child was higher than normal before any additional amino-acid was given. The administration of $10 \mathrm{~g}$. of DL-phenylalanine produced approximately equal rises in the excretion of alphaamino nitrogen in the patient and in the control. This might have been expected as DL-phenylalanine is known to be excreted rather easily by a normal person. L-tyrosine produced a moderate rise in excretion of free $\alpha$-amino nitrogen in the scorbutic infant. In the control child the excretion hardly changed. It is noteworthy that the total nitrogen excretion did not increase significantly on the days that phenylalanine or tyrosine had been given. This may be explained by the smaller food intake during these days.

Table 2 shows the excretion of the individual amino-acids during the DL-phenylalanine and L-tyrosine administration in Case 1 and the control, and Table 3 the amino-acid composition of the plasma ultrafiltrates of Cases 2 and 3 and of normal control children. For technical reasons it was not possible to determine the excretion in the urine and the plasma levels of the different amino-acids of the patients and the controls before the administration of DL-phenylalanine and L-tyrosine. We have,

TABLE 1

EXCRETION OF TOTAL AND $\alpha$-AMINO NITROGEN BEFORE AND DURING ADMINISTRATION OF DL-PHENYLALANINE AND L-TYROSINE IN SCURVY

\begin{tabular}{|c|c|c|c|c|c|}
\hline \multirow{2}{*}{ Patient } & \multirow{2}{*}{ Treatment } & \multirow[b]{2}{*}{$\begin{array}{c}\text { Urine } \\
\text { Volume } \\
\text { (ml./20 hr.) }\end{array}$} & \multirow{2}{*}{$\begin{array}{c}\text { Total } \\
\text { Urine } \\
\text { Nitrogen } \\
\text { (mg. } / 20 \mathrm{hr} \text {.) }\end{array}$} & \multicolumn{2}{|c|}{$\begin{array}{c}\text { Urine } \alpha \text {-Amino Nitrogen } \\
\text { (mg./20 hr.) }\end{array}$} \\
\hline & & & & $\begin{array}{c}\text { Before } \\
\text { Hydrolysis }\end{array}$ & $\begin{array}{c}\text { After } \\
\text { Hydrolysis }\end{array}$ \\
\hline $\begin{array}{l}\text { Scorbutic } \\
\text { Case } 1\end{array}$ & $\begin{array}{l}\text { DL-phenylalanine load* } \\
\text { L-tyrosine load* }\end{array}$ & $\begin{array}{l}220 \\
305 \\
170\end{array}$ & $\begin{array}{l}2,950 \\
2,570 \\
2,420\end{array}$ & $\begin{array}{r}52 \cdot 5 \\
166 \cdot 5 \\
66 \cdot 5\end{array}$ & $\begin{array}{r}84 \cdot 0 \\
205 \cdot 0 \\
104 \cdot 0\end{array}$ \\
\hline Control & $\begin{array}{l}\text { DL-phenylalanine load* } \\
\text { L-tyrosine load* }\end{array}$ & $\begin{array}{l}320 \\
410 \\
300\end{array}$ & $\begin{array}{l}2,550 \\
2,940 \\
3,270\end{array}$ & $\begin{array}{r}32 \cdot 5 \\
156 \cdot 0 \\
36 \cdot 0\end{array}$ & $\begin{array}{r}63 \cdot 0 \\
248 \cdot 0 \\
74 \cdot 0\end{array}$ \\
\hline
\end{tabular}


TABLE 2

URINARY EXCRETION OF FREE AMINO-ACIDS* BY SCORBUTIC AND NORMAL CHILDREN BEFORE AND DURING ADMINISTRATION OF DL-PHENYLALANINE AND L-TYROSINE

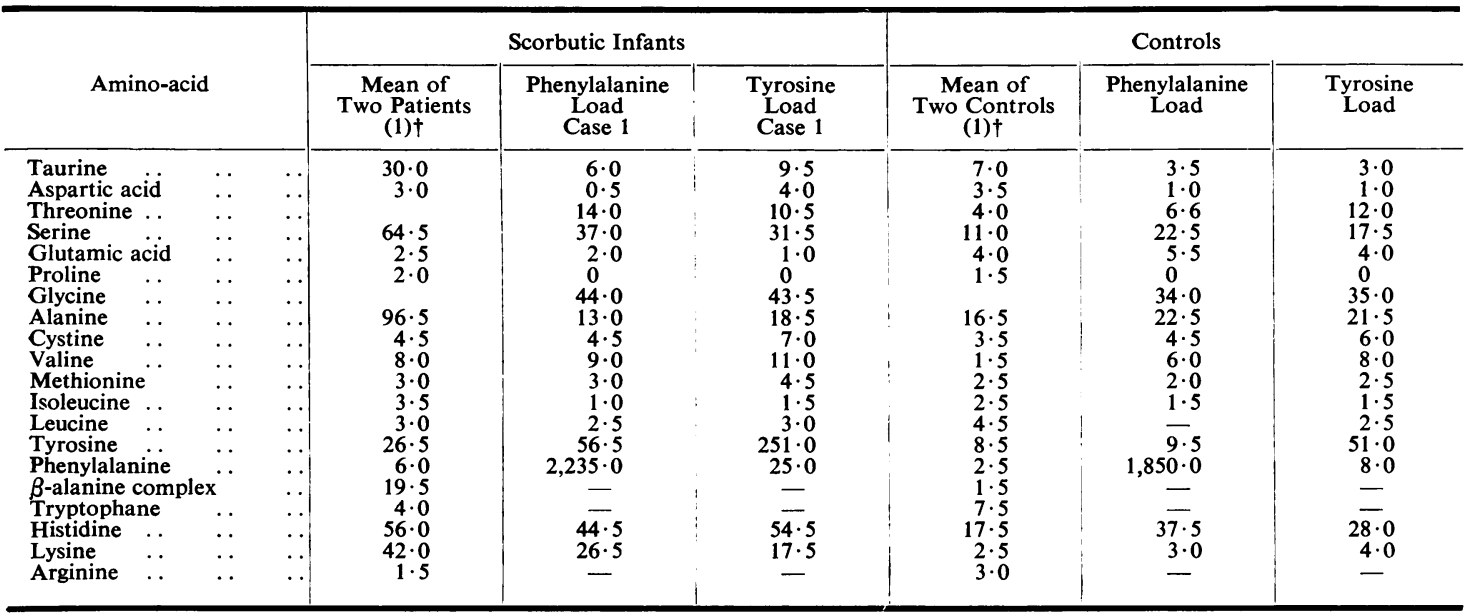

* The values are given in $\mathrm{mg} / 20$ hours.

$\dagger$ Multiplied by $20 / 24$.

therefore, compared the figures for plasma concentration and urinary excretion with the average values found for other scorbutic patients and controls whom we have examined previously (Jonxis and Huisman, 1954). The plasma concentration of the different amino-acids, except those of tyrosine and phenylalanine, did not differ much from those found in our previously published cases of normal and scorbutic children, and the excretion of the other alpha-amino acids was much the same whether the phenylalanine and tyrosine had been adminis- tered or not. Although the evaluation of the results is difficult, because the values that are being compared are obtained from different patients, the differences between the normal and scorbutic children are so striking that we believe that certain conclusions may be drawn from the collected data.

Table 2 makes it clear that during the phenylalanine and tyrosine administration Case 1 was excreting the same amino-acids (tyrosine, serine, glycine, histidine, lysine, $\beta$-amino-isobutyric acid and also taurine) in about the same increased amount

TABLE 3

AMINO-ACID COMPOSITION OF PLASMA ULTRAFILTRATES OF NORMAL AND SCORBUTIC CHILDREN BEFORE AND DURING ADMINISTRATION OF DL-PHENYLALANINE AND L-TYROSINE*

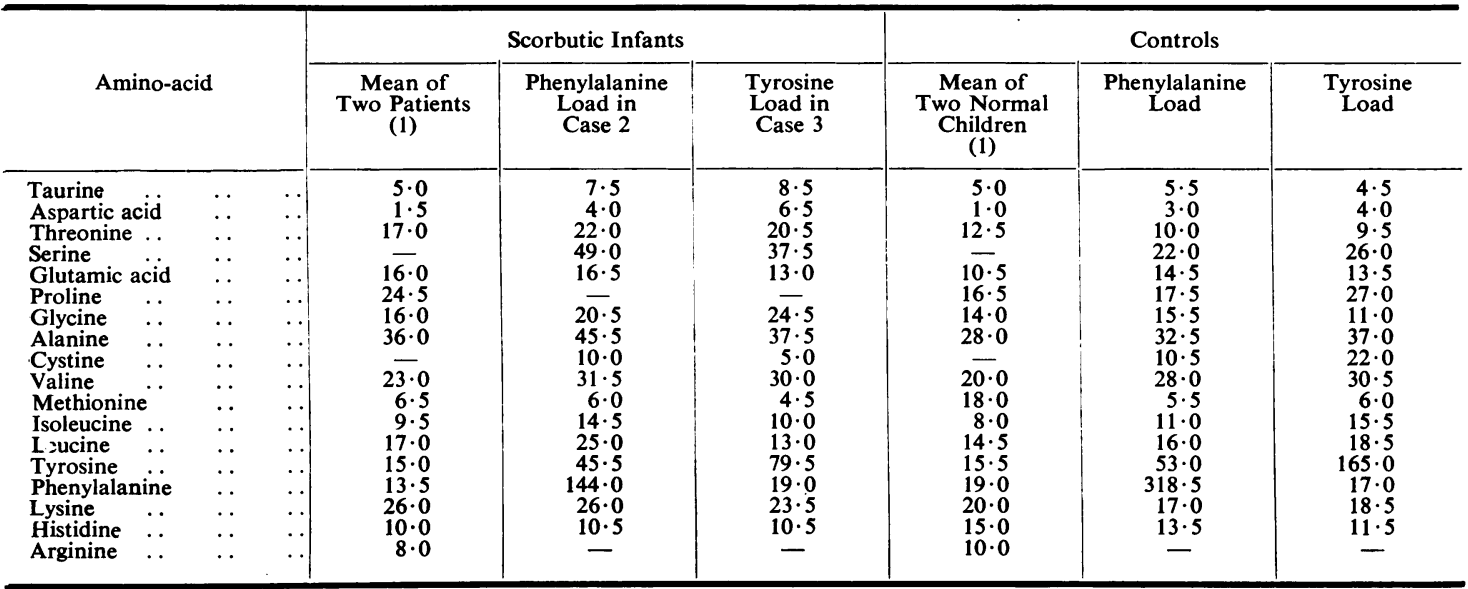

* Values given in mg./1,000 ml. 
TABLE 4

EXCRETION OF DIFFERENT METABOLITES OF PHENYLALANINE AND TYROSINE BEFORE AND DURING ADMINISTRATION

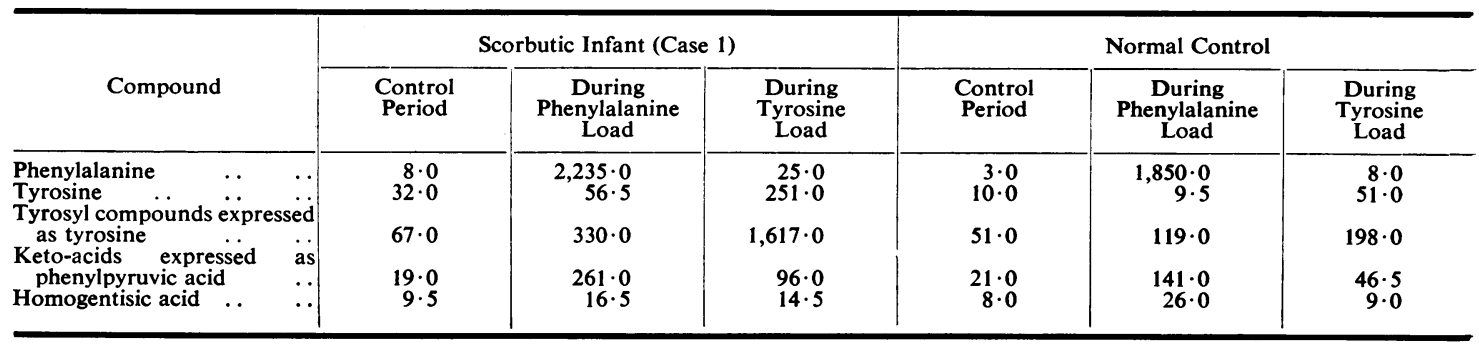

as the previously described scorbutic patients (see Table 2, first column). During the DL-phenylalanine load both the normal control and the patient were excreting much more phenylalanine, about $20 \%$ of the administered doses. The patient was excreting perhaps somewhat more than the control. It is known that the reabsorption of D-phenylalanine in the kidney tubule is limited. There was no marked influence of the phenylalanine load on the excretion of the other amino-acids except that in Case 1 the tyrosine excretion was somewhat high.

The results obtained during the L-tyrosine load show greater changes. In the control the excretion of tyrosine rose to $50 \mathrm{mg}$. The excretion of phenylalanine remained low. In Case 1 , however, the tyrosine excretion rose to about $250 \mathrm{mg}$. and at the same time the excretion of phenylalanine rose to $25 \mathrm{mg}$. In the control child the phenylalanine excretion after the tyrosine administration was $8 \mathrm{mg}$.

From the results shown in Table 3 it is seen that the administration of tyrosine or phenylalanine did not alter significantly the concentration of the other amino-acids in the plasma. As was expected, the plasma levels of tyrosine and phenylalanine were high during the administration of these aminoacids but less so in the scorbutic child than in the control. The administration of phenylalanine also affected the plasma level of tyrosine in both the patient and control. In both there was a rise from about 15 to $50 \mathrm{mg}$. per $1,000 \mathrm{ml}$. The administration of tyrosine hardly affected the plasma level of phenylalanine in either the patient or the control. The higher tyrosine excretion during the tyrosine load in scorbutic child 1 is not, therefore, likely to have been caused by a higher plasma level of tyrosine (see plasma, Case 3). On the contrary the concentration of tyrosine in the plasma of Case 3 was lower than that of the control child during the tyrosine load. A diminished reabsorption of tyrosine is the most likely explanation of the increased excretion of tyrosine in the scorbutic child. Since the phenylalanine was administered in the DL form the conclusions about phenylalanine are less clear than those for tyrosine, but again the plasma levels were lower in Case 2 than in the control. Neither tyrosine nor phenylalanine were excreted in sufficiently large amounts during their respective administrations to make excretion seem likely to be the main cause of the lower plasma levels of these amino-acids in the scorbutic children. The fact that during the administration of phenylalanine the tyrosine level of the plasma was somewhat raised, in the scorbutic as well as in the control, but not the phenylalanine level during the tyrosine administration, can be explained by the fact that phenylalanine is converted into tyrosine and not conversely. This may explain the increased tyrosine excretion during the phenylalanine administration in the scorbutic child.

Table 4 shows the results of the determination of different metabolites of tyrosine and phenylalanine in the urine of the normal control and of Case 1. The scorbutic child excreted these metabolites in normal amounts. During the phenylalanine administration the excretion increased more in the scorbutic child than in the control, but the difference was not very great. When tyrosine was given the excretion of tyrosyl compounds rose about ten times as much in the scorbutic child as in the control. This effect has already been described by Rogers and Gardner (1949). It is noteworthy that the excretion of these tyrosyl substances (mainly para-hydrophenyllactic acid) is caused by the administration of tyrosine and not by that of phenylalanine. This is in accordance with the theory that in scurvy there is an impairment in the turnover of para-hydroxyphenylpyruvic acid into 2-5 dihydroxyphenylpyruvic acid.

\section{Summary}

DL-phenylalanine and L-tyrosine were administered by mouth to three scorbutic children, and the excretion in the urine and the plasma levels of these 
and other amino-acids were determined. Both with and without additional tyrosine the excretion of tyrosine by scorbutic children was found to be much higher than by normal children. Since the plasma levels of phenylalanine and tyrosine were found to be low during the administration of these amino-acids, this amino-aciduria is thought likely to be of renal origin. As it has already been described by other authors the excretion of tyrosine substances is greatly increased in scorbutic children after the oral administration of tyrosine.

REFERENCES

Felix, K. and Schaefer, H. (1950). Hoppe-Seyl. Z. physiol. Chem., 286, 38.
- Leonhardi, G. and Glasenapp, I. von (1951). Ibid., 287, 133.

Huisman, T. H. J. (1954). Pediatrics, 14, 245.

Jonxis, J. H. P. and Huisman, T. H. J. (1954). Ibid., 14, 238. and 251 .

Levine, S. Z., Gordon, H. H. and Marples, E. (1941). J. clin. Invest., 20. 209.

Medes, G. (1932). Biochem. $J$ 26, 917.

Meore, S. and Stein, W. H. (1954). J. biol. Chem., 211, 893.

Moore, S. and Stein, W. H. (1954). J. biol. Chem., 211, 893. Invest., 29, 325.

Neuberger, A. (1947). Biochem. J., 41, 431

Rogers, W. F., Jr. and Gardner, F.'(1949). J. clin. Invest., $28,806$. Salmon, R. J. and May, C. D. (1950). J. Lab. clin. Med., 36, 591.

- (1953). Ibid., 41, 376.

Sealock, R. R. and Silberstein, H. E. (1940). J. biol. Chem., 135, 251 Stein, W. H., Bearn, A. G. and Moore, S. (1954). J. clin. Invest. 33, 410 .

Van Slyke, D. D. Dillon, R. T., MacFadyen, D. A. and Hamilton, P. (1941) J. biol Chem. 141, 627

Woodruff, C. W. (1950). J. Lab. clin. Med., 36, 640. 